\title{
Spectroscopic Definition of a Highly Reactive Site in Cu-CHA for Selective Methane Oxidation: Tuning a mono- $\mu$-oxo dicopper(II) Active Site for Reactivity
}

Hannah M. Rhoda ${ }^{\dagger+}$, Dieter Plessers ${ }^{\ddagger+}$, Alexander J. Heyer ${ }^{\dagger}$ Max L. Bols ${ }^{\ddagger}$, Robert A. Schoonheydt $t^{\ddagger \star}$, Bert F. Sels ${ }^{\ddagger \star}$ and Edward I. Solomon ${ }^{\dagger, \S^{*}}$

+ Department of Chemistry, Stanford University, Stanford, California 94305, United States

$\ddagger$ Department of Microbial and Molecular Systems, Center for Sustainable Catalysis and Engineering, KU Leuven, Celestijnenlaan 200F, B-3001 Leuven, Belgium

$\S$ Photon Science, SLAC National Accelerator Laboratory, 2575 Sand Hill Road, Menlo Park, California 94025, United States

+ These authors contributed equally to this work

\section{Abstract}

Using UV-Vis and resonance Raman spectroscopy, we identify a $\left[\mathrm{Cu}_{2} \mathrm{O}\right]^{2+}$ active site in

$\mathrm{O}_{2}$ and $\mathrm{N}_{2} \mathrm{O}$ activated $\mathrm{Cu}-\mathrm{CHA}$ that reacts with methane to form methanol at low temperature. The $\mathrm{Cu}-\mathrm{O}-\mathrm{Cu}$ angle $\left(120^{\circ}\right)$ is smaller than for the $\left[\mathrm{Cu}_{2} \mathrm{O}\right]^{2+}$ core on $\mathrm{Cu}-\mathrm{MFI}$ $\left(140^{\circ}\right)$ and its coordination geometry to the zeolite lattice is different. Site-selective kinetics obtained by operando UV-Vis show that the $\left[\mathrm{Cu}_{2} \mathrm{O}\right]^{2+}$ core on $\mathrm{Cu}-\mathrm{CHA}$ is more reactive than the $\left[\mathrm{Cu}_{2} \mathrm{O}\right]^{2+}$ site in $\mathrm{Cu}-\mathrm{MFI}$. From DFT calculations we find that the increased reactivity of $\mathrm{Cu}-\mathrm{CHA}$ is a direct reflection of the strong $\left[\mathrm{Cu}_{2} \mathrm{OH}\right]^{2+}$ bond formed along the $\mathrm{H}$-atom abstraction reaction coordinate. A systematic evaluation of these $\left[\mathrm{Cu}_{2} \mathrm{O}\right]^{2+}$ cores reveals that the higher $\mathrm{O}-\mathrm{H}$ bond strength in $\mathrm{Cu}-\mathrm{CHA}$ is due to the relative orientation of the two planes of the coordinating bidentate O-Al-O T-sites that connect the $\left[\mathrm{Cu}_{2} \mathrm{O}\right]^{2+}$ core to the zeolite lattice. This work along with our earlier study $(\mathrm{J}$. Am. Chem. Soc. 2018, 140, 9236-9243.) elucidates how zeolite lattice constraints can influence active site reactivity.

\section{Introduction}


The direct conversion of methane into methanol would have large advantages in industry as current processes to produce methanol require harsh and expensive conditions. This one-step oxidation is difficult due to the strong $\mathrm{C}-\mathrm{H}$ bond of $\mathrm{CH}_{4}$ and the
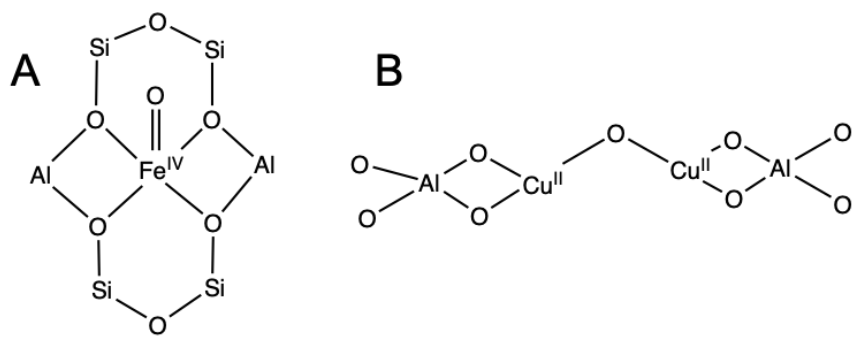

Scheme 1: A) Structure of alpha-O site located in a 6MR B) Structure of $\left[\mathrm{Cu}_{2} \mathrm{O}\right]^{2+}$ site with bidentate O-Al-O T-Site coordination. tendency for further oxidation of the methanol product. ${ }^{1,2}$ In nature, the $\mathrm{Cu}$ - and Fe- enzymes particulate and soluble methane monooxygenase (pMMO and sMMO) catalyze this

reaction at ambient conditions, but the nature of the active sites in these enzymes remains an open issue..$^{3-7} \mathrm{Cu}$ - and Fe- doped zeolites also convert methane to methanol in the gas phase at relatively low temperatures ${ }^{8-12}$ The iron active site, alpha$\mathrm{O}$, has been well defined as a high-spin $\mathrm{Fe}(\mathrm{IV})=\mathrm{O}$ site located in a 6 -membered zeolite ring (Scheme 1, A) and can react with methane at room temperature. ${ }^{9,13}$ This alpha-O site is formed when the alpha-Fe precursor reacts with $\mathrm{N}_{2} \mathrm{O}$ at $160^{\circ} \mathrm{C} .{ }^{13}$ Whether alpha$\mathrm{O}$ can be formed by $\mathrm{O}_{2}$ and in what topologies is an open issue. ${ }^{14} \mathrm{In}$ Cu zeolites, a variety of active sites has been proposed to hydroxylate methane ${ }^{12,15-18}$ but only the $\left[\mathrm{Cu}_{2} \mathrm{O}\right]^{2+}$ active sites in Cu-MFI and Cu-MOR (Scheme 1, B) have been well-defined in terms of structure and reactivity. ${ }^{8,10}$ These $\left[\mathrm{Cu}_{2} \mathrm{O}\right]^{2+}$ sites have the advantage of being generated with $\mathrm{O}_{2}$ in addition to $\mathrm{N}_{2} \mathrm{O}$, however they are less reactive with $\mathrm{CH}_{4}$ than the alpha-O site in Fe-zeolites that can react at room temperature. Identifying a $\mathrm{Cu} / \mathrm{O}$ active site that can react at a lower temperature would be advantageous for potential applications in $\mathrm{CH}_{4}$ conversion and abatement. ${ }^{19}$ 
Copper-exchanged CHA zeolites have received significant research interest recently, both for their outstanding DeNOx capabilities, being commercialized for selective catalytic reduction (SCR) of NOx gasses in heavy vehicles, ${ }^{20-22}$ and for their partial methane oxidation performance. ${ }^{23} \mathrm{Cu}-\mathrm{CHA}$ zeolites activated with either $\mathrm{O}_{2}$ or $\mathrm{N}_{2} \mathrm{O}$ can react with methane to form methanol at $200^{\circ} \mathrm{C} \cdot{ }^{15,16,24}$ Building on past studies on $\mathrm{Cu}-\mathrm{MFI}^{10}$ and $\mathrm{Cu}-\mathrm{MOR},{ }^{8,25} \mathrm{O}_{2}$ activated $\mathrm{Cu}-\mathrm{CHA}$ has been studied by several groups using diffuse reflectance (DR-UV-Vis-NIR) and resonance Raman (rR) spectroscopies. ${ }^{15,16,26,27}$ This has led to various active site proposals and combinations thereof, including a trans- $\mu-1,2-$ peroxo dicopper(II) species $\left([\mathrm{CuOOCu}]^{2+}\right)$, a mono- $\mu-$ oxo dicopper(II) species $\left(\left[\mathrm{Cu}_{2} \mathrm{O}\right]^{2+}\right)$ and $\mathrm{Cu}(\mathrm{II})$ superoxo species (both end-on and sideon). ${ }^{15,16,26}$

Due to the simple structure with a unique $\mathrm{T}$-site and its relevant applications, Cu-CHA is a model-system for understanding structure-activity relationships in zeolite catalysis, which

A

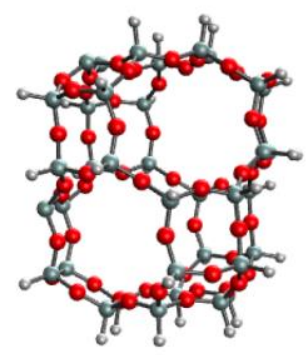

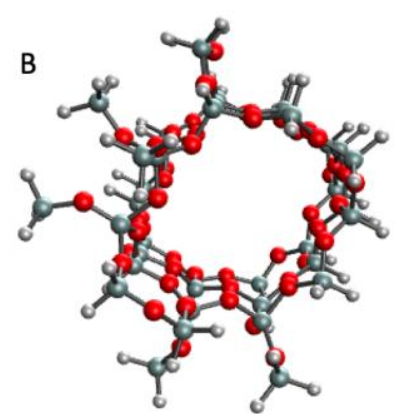

Scheme 2. A) Cage structure in CHA lattice with $8 \mathrm{MR}$ windows B) $10 M R$ channel in MFI lattice makes a correct assignment of its active Cu site an important addition to the field. ${ }^{23}$ To unambiguously determine the active site(s) responsible for methane activation in $\mathrm{O}_{2}$ activated $\mathrm{Cu}-\mathrm{CHA}$, we performed an indepth spectroscopic study. By collecting the rR excitation profile, extending the $r R$ spectrum out to a higher energy region, identifying active site formation with $\mathrm{N}_{2} \mathrm{O}$, and using an ${ }^{18} \mathrm{O}_{2}$ perturbation of the $\mathrm{rR}$ vibrations, we elucidated the presence of a $\left[\mathrm{Cu}_{2} \mathrm{O}\right]^{2+}$

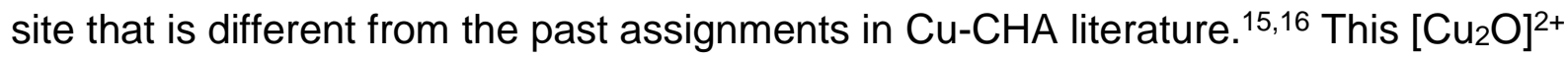


also differs structurally from the one found in Cu-MFI, leading to higher methane activation reactivity $\left(\left[\mathrm{Cu}_{2} \mathrm{O}\right]^{2+}\right.$ in $\mathrm{CHA}$ is $\sim 3$ times more reactive than $\mathrm{MFI}$ at $\left.25^{\circ} \mathrm{C}\right)$. Using DFT, two contributions to reactivity were evaluated: the different contributions of physisorption in a Cu-CHA cage versus a 10MR channel in Cu-MFI (Scheme 2), and the differences in the $\left[\mathrm{Cu}_{2} \mathrm{O}\right]^{2+}$ active site structure. Complementing our earlier study on Cu-MOR where confinement increased physisorption and influenced reactivity, ${ }^{25}$ the results here define a second means through which second sphere effects of the zeolite lattice contribute to reactivity. These structure-reactivity insights can help guide the engineering process towards materials with $\mathrm{Cu} / \mathrm{O}$ active sites that exhibit higher reactivity, similar to alpha-O sites in Fe-zeolites. Combined with the advantage of using $\mathrm{O}_{2}$ as an oxidant in $\mathrm{Cu}$-zeolites, this will broaden their potential applications.

\section{Results and Analysis}

\subsection{Physical properties}

Cu-CHA samples were prepared with $\mathrm{Si} / \mathrm{Al}=15.7$ and $\mathrm{Cu} / \mathrm{Al}=0.29(1.8 \mathrm{wt} \% \mathrm{Cu})$ according to the procedure in the Experimental Sections 1 and 2 in the SI. PXRD patterns of the calcined $\mathrm{H}-\mathrm{CHA}$ materials as well as the $\mathrm{Cu}-\mathrm{CHA}$ samples after $\mathrm{Cu}$ ion exchange (Experimental Section 2 in SI) and after a reaction cycle correspond to the standard pattern of pure, crystalline $\mathrm{H}-\mathrm{CHA}$ zeolites with no large copper oxide clusters (Figure S1). The microporosity was determined by $\mathrm{N}_{2}$ physisorption on calcined $\mathrm{H}-\mathrm{CHA}$ $\left(0.30 \mathrm{~cm}^{3} / \mathrm{g}\right)$ and $\mathrm{Cu}-\mathrm{CHA}\left(0.28 \mathrm{~cm}^{3} / \mathrm{g}\right)$, in good agreement with literature (Figure S2). ${ }^{15}$

\subsection{DR-UV-Vis-NIR Spectroscopy of the Active Copper Site}


DR-UV-Vis-NIR spectra were measured after each sequential step in the activation procedure (Experimental Section 3 in SI). The DR-UV-Vis-NIR spectra of Cu$\mathrm{CHA}$ after calcination in $\mathrm{O}_{2}$ flow at $450^{\circ} \mathrm{C}$, autoreduction in $\mathrm{He}$ flow at $700^{\circ} \mathrm{C}, \mathrm{N}_{2} \mathrm{O}$ activation at $550^{\circ} \mathrm{C}$ and after $\mathrm{CH}_{4}$ reaction at $200^{\circ} \mathrm{C}(1 \mathrm{~atm}, 60$ minutes) are shown in Figure $1 \mathrm{~A}$. Figure $1 \mathrm{~B}$ shows the analogous cycle replacing $\mathrm{N}_{2} \mathrm{O}$ with $\mathrm{O}_{2}$ in the activation step.
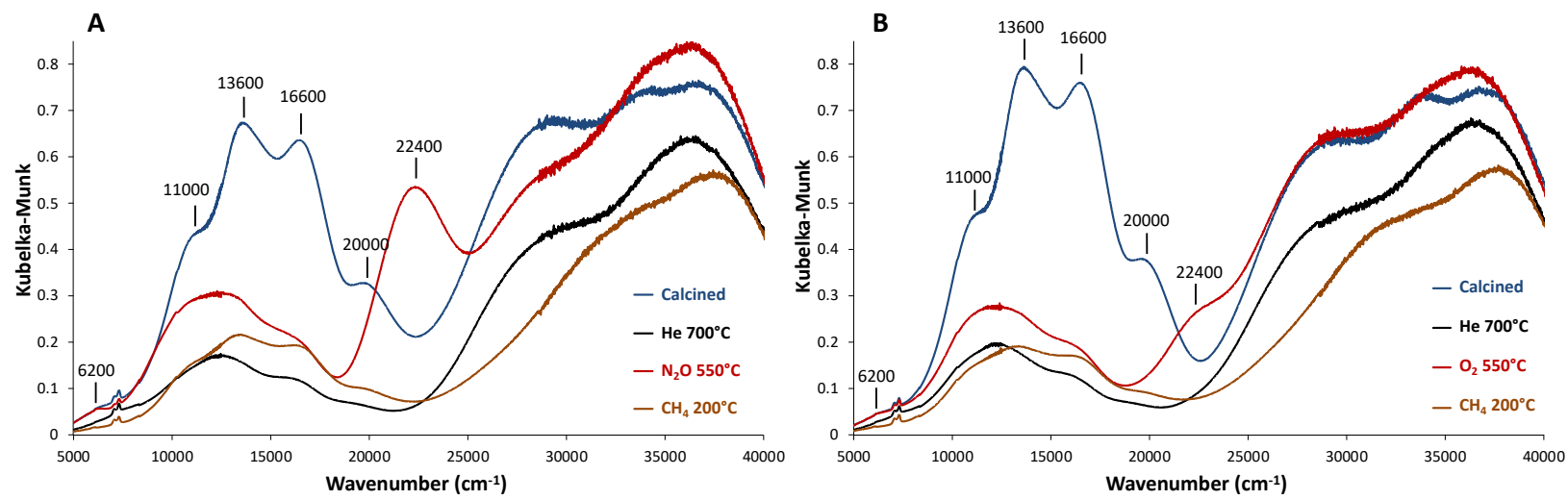

Figure 1. DR-UV-Vis NIR spectra after each step of a typical Cu-CHA activation cycle with $A) \mathrm{N}_{2} \mathrm{O}$ as the oxidant and B) $\mathrm{O}_{2}$ as the oxidant.

After the calcination step, four $\mathrm{Cu}^{2+} \mathrm{d}-\mathrm{d}$ absorption bands can be distinguished at $11,000,13,600,16,600$ and $20,000 \mathrm{~cm}^{-1}$. These bands have often been observed in literature, ${ }^{15,26-31}$ but an unequivocal assignment in terms of location or coordination of the $\mathrm{Cu}^{2+}$ has not yet been made.

After the autoreduction step in $\mathrm{He}$ at $700^{\circ} \mathrm{C}$, the intensity of the $\mathrm{Cu}^{2+} \mathrm{d}-\mathrm{d}$ bands has reduced, indicating that part of the $\mathrm{Cu}^{2+}$ has been converted to $\mathrm{Cu}^{+}$. $\mathrm{A}$ similar autoreduction occurs in $\mathrm{He}$ at $500^{\circ} \mathrm{C}$ (Figure S3).

Upon treatment with $\mathrm{N}_{2} \mathrm{O}$ or $\mathrm{O}_{2}$ at $550^{\circ} \mathrm{C}$, an absorption band appears around $22,400 \mathrm{~cm}^{-1}$, accompanied by a weaker absorption band around $6,200 \mathrm{~cm}^{-1}$. Both bands are more intense after $\mathrm{N}_{2} \mathrm{O}$ than after $\mathrm{O}_{2}$. Similar 6,200 and $\sim 22,000 \mathrm{~cm}^{-1}$ absorption bands in Cu-MOR ${ }^{8}$ and $\mathrm{Cu}-\mathrm{MFI}^{10}$ were assigned using rR spectroscopy and ${ }^{18} \mathrm{O}$ 
perturbation to $\left[\mathrm{Cu}_{2} \mathrm{O}\right]^{2+}$ species that react with methane to form methanol. A linear relationship between the intensity of this absorption band and methanol production was previously obtained for Cu-MFI. ${ }^{32}$

The $22,400 \mathrm{~cm}^{-1}$ band disappears after 60 minutes of exposure to methane at $200^{\circ} \mathrm{C}$ (Figure 1), but not in Helium (Figure S4), indicating a reaction with methane. Liquid extraction (see Experimental Section 4 in the SI) recovers $82.2 \mu \mathrm{mol}$ methanol/g for $\mathrm{N}_{2} \mathrm{O}$ activated $\mathrm{Cu}-\mathrm{CHA}$ and $63.6 \mu \mathrm{mol}$ methanol/g for $\mathrm{O}_{2}$ activated $\mathrm{Cu}-\mathrm{CHA}$. The molar methanol/Cu ratios are 0.29 and 0.22 respectively for $\mathrm{N}_{2} \mathrm{O}$ and $\mathrm{O}_{2}$ activation, comparable to the largest values reported in literature. ${ }^{16}$ Absorption bands around $28,100 \mathrm{~cm}^{-1}$ and $35,300 \mathrm{~cm}^{-1}$ were also lost in the $\mathrm{CH}_{4}$ reaction step (See UV-Vis difference spectra in Figure S5). Both have been linked to methanol production in literature, ${ }^{15,27,28}$ however their decay does not correlate with that of the $22,400 \mathrm{~cm}^{-1}$ band and they were already present after $\mathrm{He} 700^{\circ} \mathrm{C}$, suggesting they represent different sites. Methane reaction immediately after $\mathrm{He} 700^{\circ} \mathrm{C}$ (no $\mathrm{O}_{2}$ or $\mathrm{N}_{2} \mathrm{O}$ activation) recovers $25.0 \mu \mathrm{mol}$ methanol/g, which we attribute to the copper species related to the 28,100 $\mathrm{cm}^{-1}$ and $35,300 \mathrm{~cm}^{-1}$ absorption bands (Figure 1). Similar methanol production of autoreduced Cu-zeolites after reaction with $\mathrm{CH}_{4}$ has been observed in other systems. ${ }^{15,33,34}$

\subsection{Spectroscopic Definition of the Active Copper Site}


Laser excitation into the $22,400 \mathrm{~cm}^{-1}$ absorption feature resonantly enhances similar vibrations in both the $\mathrm{N}_{2} \mathrm{O}$ and $\mathrm{O}_{2}$ activated $\mathrm{Cu}-\mathrm{CHA}$ that are not observed after the autoreduction step (Figure 2). Like the $22,400 \mathrm{~cm}^{-1}$ band, these are not present before activation and are eliminated upon reaction with methane (Figure S6). The vibrations resonantly enhanced in the $\mathrm{N}_{2} \mathrm{O}$ activated $\mathrm{Cu}-\mathrm{CHA}$ sample

(Figure 2, middle) are identical to those enhanced in the $\mathrm{O}_{2}$ activated Cu-CHA sample

(Figure 2, bottom). The vibrations are more intense in the $\mathrm{N}_{2} \mathrm{O}$ activated sample consistent with the more intense

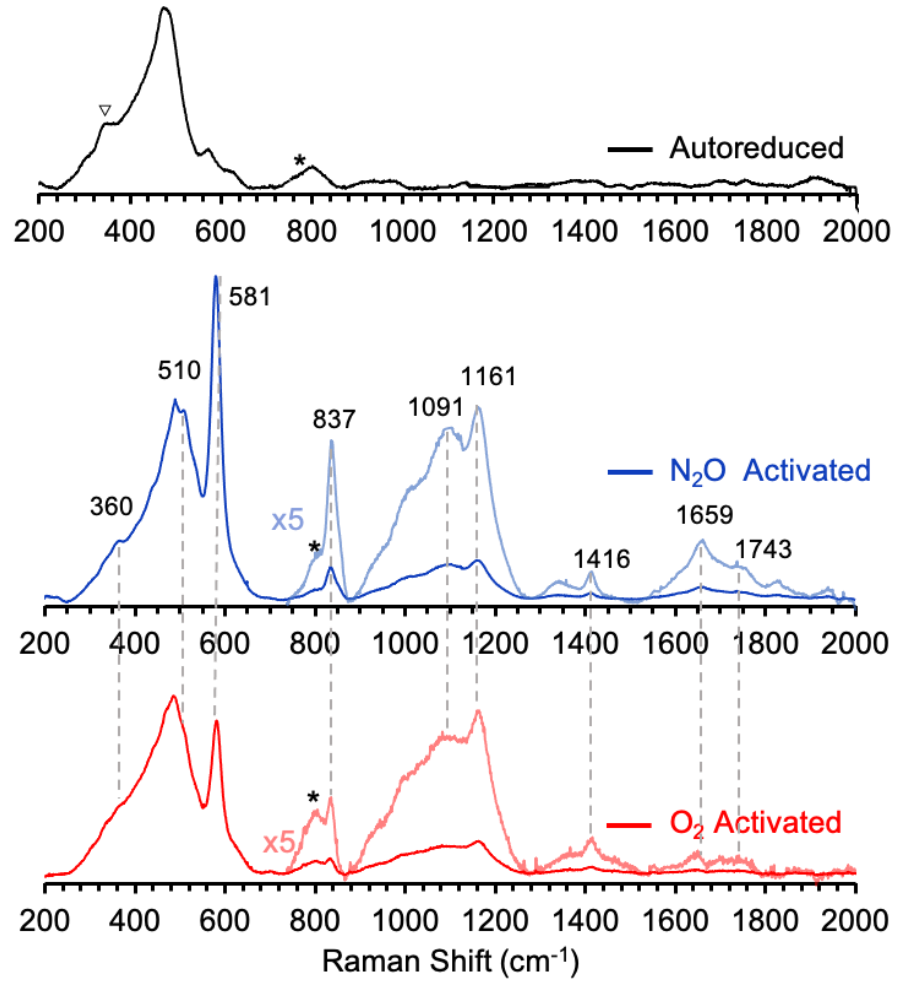

Figure 2. Comparison of the resonance Raman spectra $\left(\lambda_{\mathrm{ex}}=\right.$ $458 \mathrm{~nm}$ ) of autoreduced (top black), $\mathrm{N}_{2} \mathrm{O}$ activated (middle blue) and $\mathrm{O}_{2}$ activated (bottom red) $\mathrm{Cu}-\mathrm{CHA}$. The features that are resonantly enhanced are identified by the dotted lines $\left({ }^{*}\right.$ indicates a feature from the glass sample holder, $\nabla$ indicates a lattice feature in the autoreduced sample). The $\mathrm{rR}$ spectrum of $\mathrm{H}-\mathrm{CHA}$ can be found in SI Figure 7 for reference.

$22,400 \mathrm{~cm}^{-1}$ band in the $\mathrm{N}_{2} \mathrm{O}$ activated $\mathrm{Cu}-\mathrm{CHA}$ in Figure $1 \mathrm{~A}$. Thus, the same species is formed upon activation of the autoreduced zeolite with either $\mathrm{O}_{2}$ or $\mathrm{N}_{2} \mathrm{O}$. Scanning the rR laser lines along the $22,400 \mathrm{~cm}^{-1}$ chromophore demonstrates that all these vibrations profile with the $22,400 \mathrm{~cm}^{-1}$ absorbance indicating that all the vibrations are associated with the same species (Figure 3). 
The most intense Raman feature in Figure 2 at $581 \mathrm{~cm}^{-1}$ is found to be ${ }^{18} \mathrm{O}_{2}$ isotope sensitive $\left(\Delta\left({ }^{18} \mathrm{O}_{2}\right)=21 \mathrm{~cm}^{-1}\right.$, see Figure S8) as well as the features at $837 \mathrm{~cm}^{-1}$ $\left(\Delta\left({ }^{18} \mathrm{O}_{2}\right)=43 \mathrm{~cm}^{-1}\right)$ and $1161 \mathrm{~cm}^{-1}\left(\Delta\left({ }^{18} \mathrm{O}_{2}\right)=32 \mathrm{~cm}^{-1}\right)$. No other isotope shifts were observed above noise due to the lower Raman intensity of $\mathrm{O}_{2}$ activated $\mathrm{Cu}-\mathrm{CHA}$ and an incomplete labeling with ${ }^{18} \mathrm{O}_{2}$.

Cu-MFI and Cu-MOR stabilize $\left[\mathrm{Cu}_{2} \mathrm{O}^{2+}\right.$ cores that can be formed with both $\mathrm{O}_{2}$ and $\mathrm{N}_{2} \mathrm{O}$ and exhibit similar $\mathrm{rR}$ features that are associated with their $\sim 22,000 \mathrm{~cm}^{-1}$
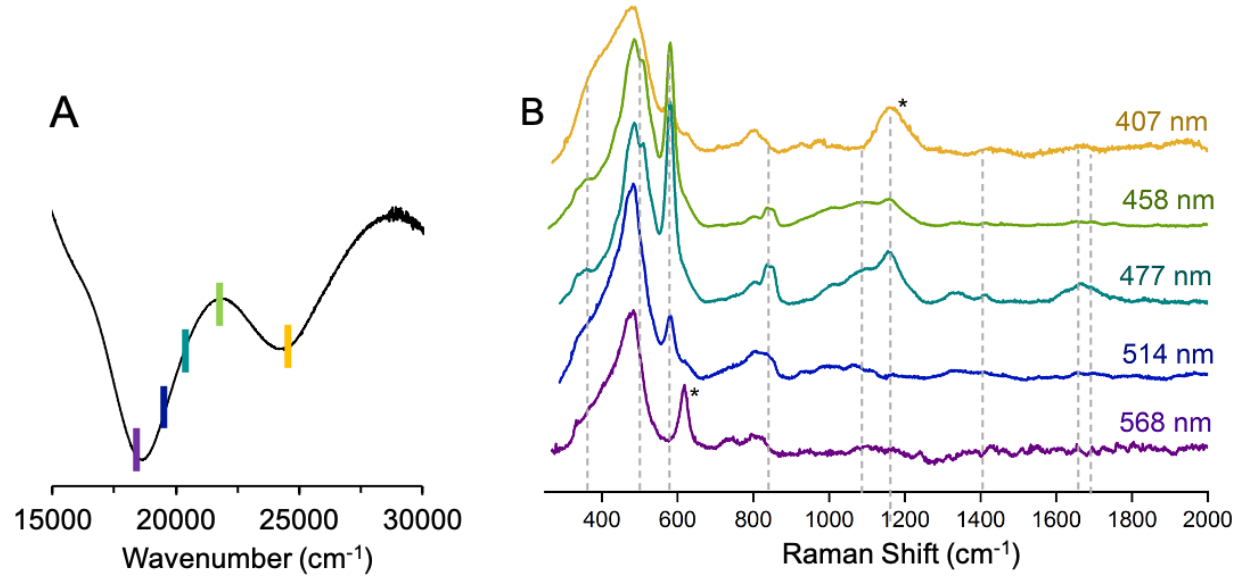

absorbance

bands. ${ }^{8,10}$

Based on this

similarity, the

most intense

feature at 581

Figure 3: A) Zoom in of the $22,400 \mathrm{~cm}^{-1}$ DR UV-Vis absorbance feature. B) Full rR profile of the $22,400 \mathrm{~cm}^{-1}$ absorption feature formed upon activation with $\mathrm{N}_{2} \mathrm{O}$. Bars on the $22,400 \mathrm{~cm}^{-1}$ absorbance spectrum in $A$ are the energies of the $r R$ lines used in (B). Dotted lines on the $\mathrm{rR}$ spectrum indicate features in resonance with the absorbance feature. $\left({ }^{*}\right)$ indicates features that are not resonantly enhanced by the $22,400 \mathrm{~cm}^{-1}$ feature but are enhanced by other bands.

$\mathrm{cm}^{-1}\left(\Delta\left({ }^{18} \mathrm{O}_{2}\right)=\right.$

$\left.21 \mathrm{~cm}^{-1}\right)$ is

assigned as the

symmetric

stretch of an oxo group bridging two Cu centers and the vibration at $837 \mathrm{~cm}^{-1}$ is assigned as the oxo antisymmetric stretch. This assignment is validated by the observation of progressions in the region between $1,000 \mathrm{~cm}^{-1}$ and 2,000 $\mathrm{cm}^{-1}$ (Figure 2). The second and third quanta of the $581 \mathrm{~cm}^{-1}$ symmetric stretch are observed at 1,161 and $1,743 \mathrm{~cm}^{-1}$, respectively. The second member of a progression in the $837 \mathrm{~cm}^{-1}$ antisymmetric vibration is observed at $1,659 \mathrm{~cm}^{-1}$. The $360 \mathrm{~cm}^{-1}$ vibration is assigned as 
a Cu-O-Cu bend vibration. Finally, the tetrahedral site (T-site) ligand shows a resonance enhanced vibration at $510 \mathrm{~cm}^{-1}$ (no isotope perturbation), and this forms a combination band with the symmetric stretch $\left(581 \mathrm{~cm}^{-1}\right)$ at $1091 \mathrm{~cm}^{-1}$.

Our assignment of the $\mathrm{rR}$ features of the $\mathrm{Cu}-\mathrm{CHA}$ active site is different from those previously proposed in the literature. The features at $581 \mathrm{~cm}^{-1}$ and $837 \mathrm{~cm}^{-1}$ were previously assigned as the $\mathrm{Cu}-\mathrm{O}$ stretch and the $\mathrm{O}-\mathrm{O}$ stretch of a trans- $\mu-1,2-$ peroxo species, respectively. ${ }^{15,16}$ Trans- $\mu-1,2$-peroxo species have been extensively defined in the literature and do indeed have $\mathrm{Cu}-\mathrm{O}$ stretches between $550-600 \mathrm{~cm}^{-1}$ and $\mathrm{O}-\mathrm{O}$ stretches between $800-850 \mathrm{~cm}^{-1} .{ }^{35-38}$ However, due to the nature of the charge transfer (CT) transition responsible for the resonance enhancement in trans- $\mu-1,2-$ peroxo bridged $\mathrm{Cu}(\mathrm{II})_{2}$ sites, the $\mathrm{O}-\mathrm{O}$ stretch is more intense than the $\mathrm{Cu}-\mathrm{O}$ stretch; this intensity pattern is opposite to that experimentally observed in Cu-CHA. The $837 \mathrm{~cm}^{-1}$ feature is weak and now assigned as an antisymmetric stretch which is not $r R$ allowed in idealized $\mathrm{Cu}_{2} \mathrm{O} \mathrm{C}_{2 v}$ symmetry and the $581 \mathrm{~cm}^{-1}$ feature is intense as it is the $r R$ allowed symmetric stretch of the Cu-O-Cu core. As shown in Figure 3, all the rR enhanced vibrations of $\mathrm{Cu}-\mathrm{CHA}$ profile its absorbance feature, which is also inconsistent with a trans- $\mu-1,2$-peroxo species where the CT absorbance feature is made up of three distinct transitions that give different resonance enhancement profiles. ${ }^{35}$ In another study, the $r R$ features at $1,091 \mathrm{~cm}^{-1}$ and $1,161 \mathrm{~cm}^{-1}$ were proposed to be O-O stretches of copper superoxide species,${ }^{16}$ which are commonly observed in this energy region. ${ }^{39}$ However, if these $\mathrm{rR}$ vibrations originated from a different $\mathrm{Cu} / \mathrm{O}$ species they would not have the same resonance enhancement profile as the symmetric and antisymmetric stretches of the $\left[\mathrm{Cu}_{2} \mathrm{O}\right]^{2+}$ site and they would also not be 
formed with $\mathrm{N}_{2} \mathrm{O}$. Additionally, copper superoxide species with $\mathrm{O}-\mathrm{O}$ vibrations in this region generally have $\Delta^{18} \mathrm{O}_{2}$ shifts around $60 \mathrm{~cm}^{-1}$. Experimentally we see a smaller value $\left(\Delta^{18} \mathrm{O}_{2}=32 \mathrm{~cm}^{-1}\right)$ for the $v_{2 s y m}$ vibration at $1,161 \mathrm{~cm}^{-1}$. This is consistent with its assignment as the $2 x$ symmetric stretch which has an experimental value of $581 \mathrm{~cm}^{-1}$ $\left(\Delta\left({ }^{18} \mathrm{O}_{2}\right)=21 \mathrm{~cm}^{-1}\right)$ and a DFT calculated frequency of $543\left(\Delta\left({ }^{18} \mathrm{O}_{2}\right)=10 \mathrm{~cm}^{-1}\right)($ vide infra).

Three $\left[\mathrm{Cu}_{2} \mathrm{O}\right]^{2+}$ cores have been previously identified in other zeolite lattices, one in Cu-MFII ${ }^{10}$ and two in Cu-MOR. ${ }^{8}$ The rR spectra with $458 \mathrm{~nm}$ excitation into the $\sim 22,000 \mathrm{~cm}^{-1}$ absorbance feature of $\mathrm{Cu}-\mathrm{MFI}$ and $\mathrm{Cu}-\mathrm{CHA}$ are compared in Figure 4. The $\mathrm{rR}$ vibrations of $\mathrm{Cu}-\mathrm{CHA}$ are shifted compared to those of Cu-MFI. The red highlights in Figure 4 compare the symmetric $\left(v_{\text {sym }}\right)$ and $2 x$ symmetric (v2sym) stretches of the $\left[\mathrm{Cu}_{2} \mathrm{O}\right]^{2+}$ cores in $\mathrm{Cu}-\mathrm{MFI}$ (top) and $\mathrm{Cu}-\mathrm{CHA}$ (bottom). The $v_{\text {sym }}$ at $581 \mathrm{~cm}^{-1}$ and the $v_{2 s y m}$ at

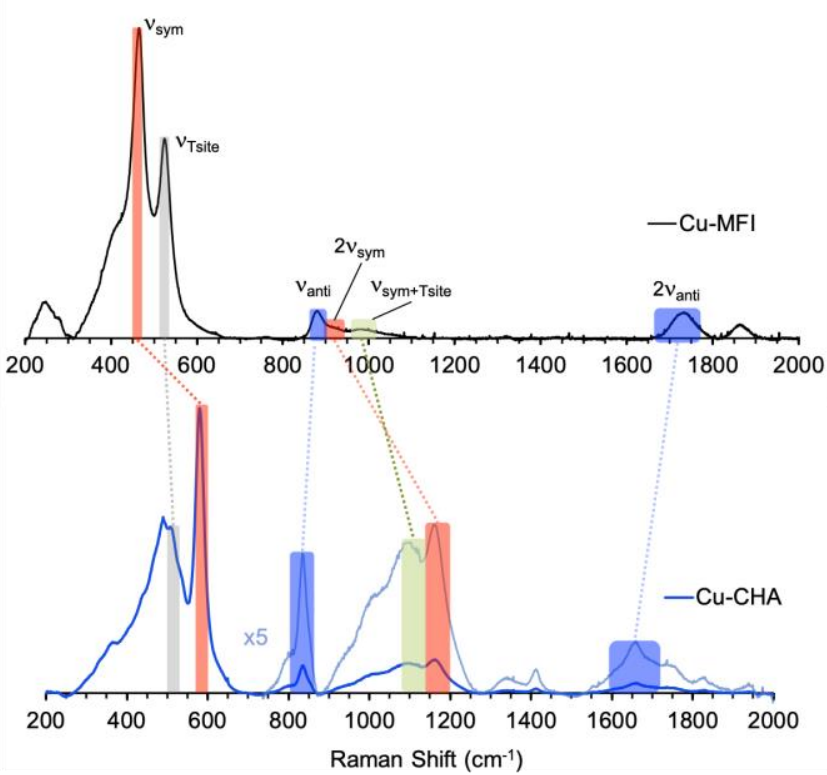

Figure 4. Comparison of the vibrations associated with the $\left[\mathrm{Cu}_{2} \mathrm{O}\right]^{2+}$ core in $\mathrm{Cu}-\mathrm{MFI}$ (top) and $\mathrm{Cu}-\mathrm{CHA}$ (bottom). The symmetric stretches are shown in the red highlights. The antisymmetric stretches are shown in the blue highlights. The T-sites are shown in the gray highlights and the combination band of the T-site + symmetric stretch is shown in the green highlights.

$1161 \mathrm{~cm}^{-1}$ in CHA are both higher in energy than in Cu-MFI (vsym at $456 \mathrm{~cm}^{-1}$ and v2sym at $\left.908 \mathrm{~cm}^{-1}\right)$. In contrast, the weaker antisymmetric (vanti) and the $2 x$ antisymmetric features (v2anti) (blue highlights in Figure 4) are shifted to lower energy in Cu-CHA 
compared to the previously assigned vibrations in Cu-MFI. Interestingly, the T-site resonance enhancement ( $v$ Tsite, gray highlight) in Cu-CHA at $510 \mathrm{~cm}^{-1}$ is located at almost the same energy as the T-site at $514 \mathrm{~cm}^{-1}$ in Cu-MFI. The $v T_{\text {site }}+v_{\text {sym }}$ combination band also increases in energy from 974 to $1091 \mathrm{~cm}^{-1}$ (green highlight) reflecting the $\sim 120 \mathrm{~cm}^{-1}$ increase in $v_{\text {sym }}$ for $\mathrm{Cu}$-CHA. A normal coordinate analysis (NCA) of a metal-oxygen-metal core ${ }^{40}$ was used to correlate the symmetric and antisymmetric vibrations (see Explanation S1) and determined that the $\mathrm{Cu}-\mathrm{O}-\mathrm{Cu}$ angle in $\mathrm{Cu}-\mathrm{CHA}$ is $120^{\circ}$, compared to $\sim 140^{\circ}$ in Cu-MFI and Cu-MOR.

\subsection{Kinetic analysis of the active site reaction with $\mathrm{CH}_{4}$ :}
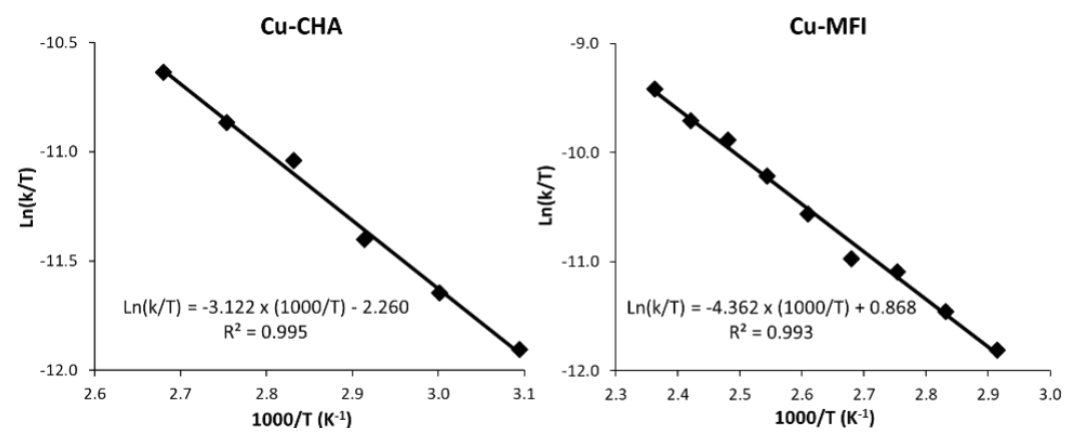

The decay of the

Figure 5. Eyring plot for the reaction of $\mathrm{CH}_{4}$ with $\left[\mathrm{Cu}_{2} \mathrm{O}\right]^{2+}$ in $\mathrm{Cu}-\mathrm{CHA}$ (left) and Cu-MFI (right).

$22,400 \mathrm{~cm}^{-1}$ band of activated $\mathrm{Cu}-\mathrm{CHA}$ and

Cu-MFI was monitored

during reaction with

methane at a series of

temperatures with

operando UV-Vis spectroscopy to obtain site-selective kinetics of $\left[\mathrm{Cu}_{2} \mathrm{O}\right]^{2+}(\mathrm{See}$

Table 1: Comparison of kinetic parameters of the $\left[\mathrm{Cu}_{2} \mathrm{O}\right]^{2+}$ species in $\mathrm{Cu}-\mathrm{CHA}$ and $\mathrm{Cu}-\mathrm{MFI}$.

\begin{tabular}{ccc} 
& $\Delta \mathbf{H}^{\ddagger}(\mathrm{kcal} / \mathrm{mol})$ & $\Delta \mathbf{S}^{\ddagger}\left(\mathrm{cal} /\left(\mathrm{mol}^{*} \mathrm{~K}\right)\right)$ \\
\hline CHA & 6.2 & -51.7 \\
MFI & 8.7 & -45.5 \\
\hline
\end{tabular}

Experimental Section 8 in SI). An Eyring

plot was obtained (Figure 5, and

Explanation S2), and from the fitted slope

and intercept an enthalpy of activation $\Delta H^{\ddagger}$ and entropy of activation $\Delta S^{\ddagger}$ were obtained for the $\left[\mathrm{Cu}_{2} \mathrm{O}\right]^{2+}$ species in $\mathrm{Cu}-\mathrm{CHA}$ and $\mathrm{Cu}-\mathrm{MFI}$ (Table 1). The enthalpy barrier is 2.5 $\mathrm{kcal} / \mathrm{mol}$ lower in Cu-CHA. 


\subsection{Active Site Models: Comparison to Experiment}

Previous studies determined that the $\left[\mathrm{Cu}_{2} \mathrm{O}\right]^{2+}$ active site in $\mathrm{Cu}-\mathrm{MFI}$ is stabilized in a $10 \mathrm{MR}$ channel, each $\mathrm{Cu}(\mathrm{II})$ with bidentate ligation to the oxygens of the $\mathrm{Al} \mathrm{T}$-site and a Cu-O-Cu angle of $140^{\circ} .{ }^{10}$ The $\mathrm{CHA}$ lattice does not contain long channels but is made up of cages connected through adjoining 8MR windows (Scheme 2, A). Large lattice models ( 150 atoms) of both the MFI channel and the CHA cage were optimized using Density Functional Theory (DFT). The model of MFI stabilizes a $\left[\mathrm{Cu}_{2} \mathrm{O}\right]^{2+}$ core on one side of a 10MR in an O-Al-O-(Si-O) $)_{2}-\mathrm{Al}-\mathrm{O}$ sequence with the oxo of the $\left[\mathrm{Cu}_{2} \mathrm{O}\right]^{2+}$ site pointed towards the middle of the ring (Figure 6, A). Due to the smaller size of the $\mathrm{CHA} 8 \mathrm{MR}$, a $\left[\mathrm{Cu}_{2} \mathrm{O}\right]^{2+}$ site with an angle of $120^{\circ}$ can only be stabilized across the 8MR and is in an O-Al-O-(SiO) ${ }_{3}-\mathrm{Al}-\mathrm{O}$ sequence with the bridging O-atom of the $\left[\mathrm{Cu}_{2} \mathrm{O}\right]^{2+}$ pointing out of the 8MR into a CHA cage

(Figure 6, B).

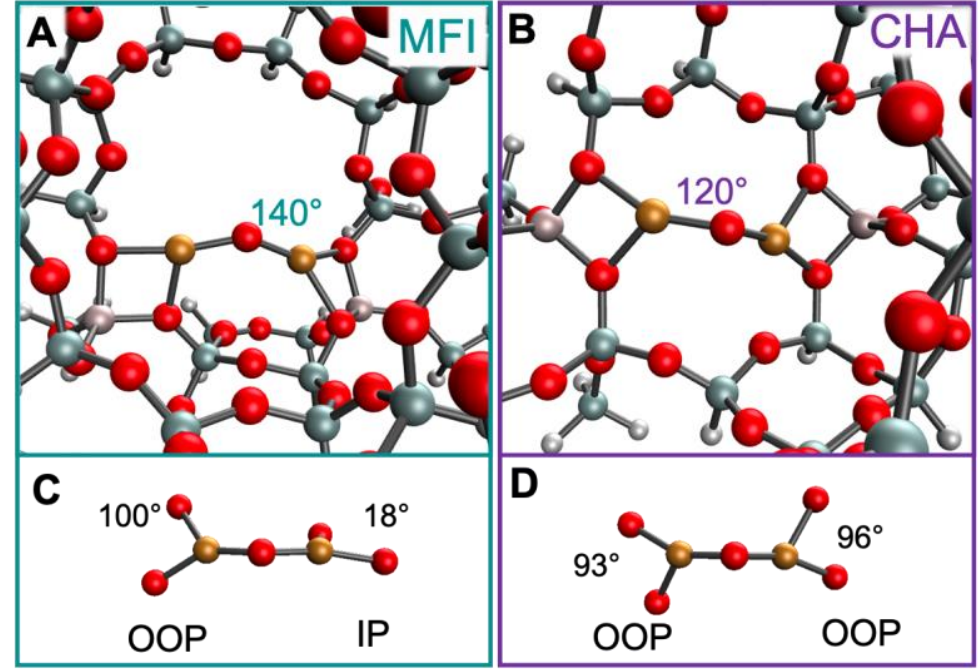

Figure 6. $\left[\mathrm{Cu}_{2} \mathrm{O}\right]^{2+}$ cores in the MFI (A, green box) and $\mathrm{CHA}(\mathrm{B}$, purple box) lattices and schematic of bidentate oxygen ligation of $\left[\mathrm{Cu}_{2} \mathrm{O}\right]^{2+}$ cores in MFI (C) and CHA (D) assigning out of plane (OOP) and in plane (IP) ligation with respect to the $\mathrm{Cu}-\mathrm{O}-\mathrm{Cu}$ plane.

Note that the $\left[\mathrm{Cu}_{2} \mathrm{O}\right]^{2+}$ active sites identified in $\mathrm{CHA}$ and MFI also differ in their bidentate coordination to the lattice oxygens of the Al T-site. In CHA, the oxygen atoms of both bidentate T-site ligands are oriented out of the Cu-O-Cu plane by $93^{\circ}$ and $96^{\circ}$ (Figure 6, D). In contrast, 
in MFI one set of bidentate lattice oxygens is more in the Cu-O-Cu plane (IP) $\left(18^{\circ}\right)$ and one set is out of plane (OOP) $\left(100^{\circ}\right)$ (Figure 6, C).

A comparison of the experimental and DFT predicted $\left[\mathrm{Cu}_{2} \mathrm{O}\right]^{2+}$ structures and spectroscopic features for both lattices are presented in Table 2. The calculated angles of the $\left[\mathrm{Cu}_{2} \mathrm{O}\right]^{2+}$ cores are in good Table 2. Comparison of experimental and predicted spectroscopic and structural features of MFI and $\mathrm{CHA}$ and their corresponding large models.

agreement with the

experimental values

determined by rR

and NCA

\begin{tabular}{lllll}
\hline & MFI (Exp) & MFI Channel & CHA (Exp) & CHA Cage \\
\hline$\angle \mathrm{Cu}-\mathrm{O}-\mathrm{Cu}$ & 140 & 140 & 120 & 126 \\
$\mathrm{~d}\left(\mathrm{Cu}-\mathrm{O}_{\text {lattice }}\right) / \AA$ & - & $1.98-2.04$ & - & $1.93-2.04$ \\
$\mathrm{~d}\left(\mathrm{Cu}-\mathrm{O}_{\text {oxo }}\right) / \AA$ & - & 1.75 & - & $1.73-1.75$ \\
$\mathrm{Abs} / \mathrm{cm}^{-1}$ & 22700 & 24930 & 22000 & $23246 / 26099$ \\
$v_{\text {sym }}\left(\Delta^{18} \mathrm{O}_{2}\right) / \mathrm{cm}^{-1}$ & $456(8)$ & $454(5)$ & $580(21)$ & $543(10)$ \\
$v_{\text {asym }}\left(\Delta^{18} \mathrm{O}_{2}\right) / \mathrm{cm}^{-1}$ & $870(40)$ & $847(41)$ & $837(43)$ & $842(40.5)$
\end{tabular}

(Explanation S1) $\left(139.5^{\circ}\right.$ vs. $140^{\circ}$ for MFI; $126^{\circ}$ vs. $120^{\circ}$ for $\left.\mathrm{CHA}\right)$. The calculated $\mathrm{Cu}-$

O-Cu symmetric and antisymmetric vibrations as well as their $\Delta{ }^{18} \mathrm{O}_{2}$ shifts reinforce the experimental assignments.

\subsection{Reaction Coordinate Calculations}

To elucidate the origin of the higher experimental reactivity of methane with the active site in Cu-CHA compared to Cu-MFI (Table 1), the $\mathrm{H}$ atom abstraction (HAA) reaction coordinates of $\mathrm{CH}_{4}$ to form $\left[\mathrm{Cu}_{2} \mathrm{OH}\right]^{2+}$ and a $\cdot \mathrm{CH}_{3}$ radical were calculated for the large lattice models, both with dispersion (solid lines) and with the dispersion removed (dotted lines) (Figure 7). The corresponding enthalpy values are given in Table 3. The difference between the calculations with and without dispersion gives an estimate of the physisorption contribution to the energetics of each step. The sites were optimized with dispersion, then the structure was fixed, and the dispersion was eliminated. Starting from the left of the reaction coordinate in Figure 7, gas phase 
methane is first physisorbed to the $\mathrm{Cu}-\mathrm{O}-\mathrm{Cu}$ active site (Reactant Complex, $\mathrm{RC}$ ). The $\mathrm{RC}$ then goes through a transition state (TS) to form a product complex (PC) which is a $\mathrm{Cu}-\mathrm{OH}-\mathrm{Cu}^{\prime \prime}$ core with a physisorbed $\cdot \mathrm{CH}_{3}$ radical. The $\cdot \mathrm{CH}_{3}$ radical was then removed from the zeolite lattice to calculate the physisorption contribution to the energetics of the product complex.

Physisorption of $\mathrm{CH}_{4}$ into the zeolite lattice was evaluated to determine its effect on the apparent activation barrier. Relative to the calculations without dispersion, methane physisorption from the gas phase to the active site is favorable by $\sim 10$ $\mathrm{kcal} / \mathrm{mol}$ (Figure 7, left to $\mathrm{RC}$ ). There is not much difference in the physisorption energetics between the CHA and MFI models, suggesting that this does not contribute to the increased reactivity in $\mathrm{CHA}$. This is in contrast to the results in MOR where the physisorption energy difference was the dominating contribution to the difference in reactivity between a more and a less confined $\left[\mathrm{Cu}_{2} \mathrm{O}\right]^{2+}$ species. ${ }^{25}$ On the right side of Figure 7, physisorption of the methyl radical to the $\mathrm{Cu}-\mathrm{OH}-\mathrm{Cu}$ product (Fig 7, right to 
$\mathrm{PC}$ ) is calculated to be favorable by $\sim 10 \mathrm{kcal} / \mathrm{mol}$. There is an additional interaction of the new $\mathrm{H}$-bond formed between the methyl radical and the $\mathrm{Cu}-\mathrm{OH}-\mathrm{Cu}$ core that results from the HAA reaction that is worth $\sim 3 \mathrm{kcal} / \mathrm{mol}$ (based on the stabilization of the $\cdot \mathrm{CH}_{3}$ radical by the $\left[\mathrm{Cu}_{2} \mathrm{OH}\right]^{2+}$ site without dispersion). Overall, the models exhibit similar physisorption into the zeolite for both the $\mathrm{CH}_{4}$ substrate and the $\cdot \mathrm{CH}_{3}$ radical.

Now focusing on the TS energies, CHA has a $4.4 \mathrm{kcal} / \mathrm{mol}$ lower TS energy compared to MFI (CHA lower by $3.3 \mathrm{kcal} / \mathrm{mol}$ in the calculations without dispersion). If we look at apparent values where we compare the $\mathrm{CH}_{4}+\left[\mathrm{Cu}_{2} \mathrm{O}\right]^{2+}$ to the HAA TS, the difference is 2.2 $\mathrm{kcal} / \mathrm{mol}$ with dispersion. This value is in good agreement with the experimental enthalpy difference with $\mathrm{CHA}$ lower than MFI by $2.5 \mathrm{kcal} / \mathrm{mol}$ (Table 1$).$ In order to determine the effect of

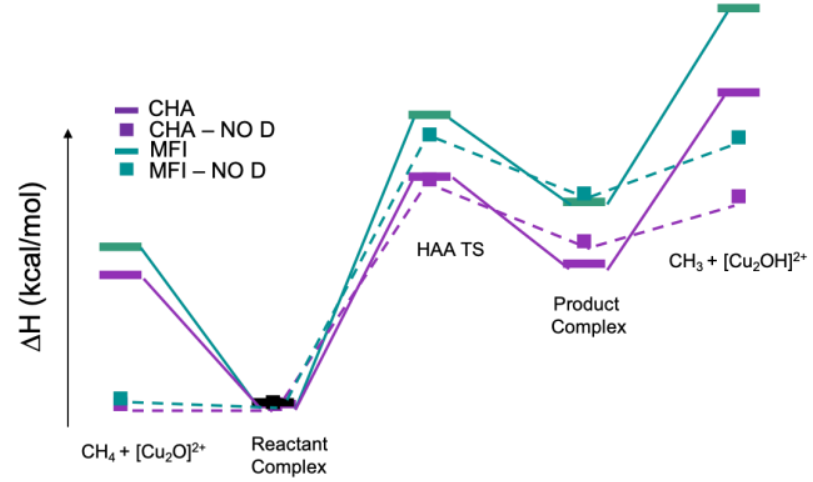

Figure 7. $\mathrm{CH}_{4}$ reaction coordinates for large channel/cage models for MFI (green) and CHA (purple). Dotted lines are calculations without dispersion. Values for each step in the reaction coordinate for each structure are given in Table 3. Reactant Complex energies are all set to zero.

Table 3. Enthalpy values ( $\mathrm{kcal} / \mathrm{mol}$ ) for the different complexes in Figure 7.

\begin{tabular}{|c|cc|cc|}
\hline \multirow{2}{*}{$\Delta \mathrm{H}(\mathrm{kcal} / \mathrm{mol})$} & \multicolumn{2}{|c|}{ no dispersion } & \multicolumn{2}{c|}{ dispersion } \\
\cline { 2 - 5 } & $\begin{array}{c}\mathrm{CHA} \\
\text { Cage }\end{array}$ & $\begin{array}{c}\mathrm{MFI} \\
\text { Channel }\end{array}$ & $\begin{array}{c}\mathrm{CHA} \\
\text { Cage }\end{array}$ & $\begin{array}{c}\mathrm{MFI} \\
\text { Channel }\end{array}$ \\
\hline $\mathrm{CH}_{4}+\left[\mathrm{Cu}_{2} \mathrm{O}\right]^{2+}$ & 0.0 & 0.4 & 9.5 & 11.7 \\
\hline Reactant Complex & 0.0 & 0.0 & 0.0 & 0.0 \\
\hline HAA Transition State & 16.6 & 19.9 & 16.9 & 21.3 \\
\hline Product Complex & 12.0 & 15.6 & 10.3 & 15.0 \\
\hline $\mathrm{CH}_{3}+\left[\mathrm{Cu}_{2} \mathrm{OH}\right]^{2+}$ & 15.4 & 19.8 & 23.0 & 29.2 \\
\hline
\end{tabular}

thermodynamics on the TS, Marcus theory ${ }^{41}$ was used to extract the intrinsic barriers (i.e. with no thermodynamic driving force, see Explanation S3). These values are given in Table 4. The calculated intrinsic barriers for the $\mathrm{Cu}-\mathrm{CHA}$ and $\mathrm{Cu}-\mathrm{MFI}$ reaction 
coordinates in the large lattice models are similar (11.2 vs. $12.7 \mathrm{kcal} / \mathrm{mol})$ indicating that most of the $4.4 \mathrm{kcal} / \mathrm{mol}$ of TS difference is due to the thermodynamic difference between the reactant and the product.

The difference in energy of the two extremes on the reaction coordinate in Figure 7 (where the $\mathrm{CH}_{4}$ and $\cdot \mathrm{CH}_{3}$ are in the gas phase removed from the active site cores) gives direct insight into the thermodynamics for the reaction coordinate, reflecting the strength of the $\mathrm{O}-\mathrm{H}$ bond formed along the HAA reaction coordinate (values are given in Table 4). The O-H bond formed in $\mathrm{Cu}-\mathrm{CHA}$ is calculated to be 4 Table 4: HAA Transition State energies (in $\mathrm{kcal} / \mathrm{mol}$ ), Marcus corrected intrinsic barriers and calculated $\mathrm{O}-\mathrm{H}$ bond strengths for the large lattice models (with respect to the $103.3 \mathrm{kcal} / \mathrm{mol}$ calculated $\mathrm{C}-\mathrm{H}$ bond of $\mathrm{CH}_{4}$ ).

$\mathrm{kcal} / \mathrm{mol}$ stronger than $\mathrm{MFI}$.

\begin{tabular}{|c|c|c|c|}
\hline$\Delta H$ (kcal/mol) & HAA Transition State & Intrinsic Barrier & OH Bond Strength \\
\hline CHA CAGE & 16.9 & 11.2 & 89.8 \\
\hline MFI Channel & 21.3 & 12.7 & 85.8 \\
\hline
\end{tabular}

Therefore, the higher reactivity

exhibited in $\mathrm{Cu}-\mathrm{CHA}$ is due to the stronger $\mathrm{O}-\mathrm{H}$ bond that forms in $\mathrm{Cu}-\mathrm{CHA}$. We also calculated HAA reaction coordinates for small ring models (SRMs) that do not include the walls of the zeolite lattice. These SRMs reproduce the trends observed in the large lattice models (Explanation S4).

To determine the geometric and electronic structure contributions to this $\mathrm{OH}$ bond strength difference between $\mathrm{CHA}$ and $\mathrm{MFI}$, smaller models were developed by extracting the $\mathrm{Cu}-\mathrm{O}-\mathrm{Cu}$ reactant and $\mathrm{Cu}-\mathrm{OH}-\mathrm{Cu}$ product cores along with their coordinating O-Al-O T-sites from the large lattice models (Figure 8). The lattice Si atoms capping the Al T-sites were replaced with hydrogen atoms set along the bond direction to a bond length of $0.96 \AA$. To ensure that the small core model had the same coordinates (angles, bond lengths, bidentate $\mathrm{O}$ angles, etc.) as the larger lattice models, 
no additional optimization was performed after extracting the core and capping the AI Tsites with hydrogens. A single point calculation was performed to obtain the energy of each structure. These extracted core models of MFI and $\mathrm{CHA}$ have the same number of atoms and electrons and can be directly compared (Figure 8).

The reactant $\mathrm{Cu}-\mathrm{O}-\mathrm{Cu}$ core in Cu-CHA was calculated to be 4.1 $\mathrm{kcal} / \mathrm{mol}$ higher in energy than in $\mathrm{Cu}-$

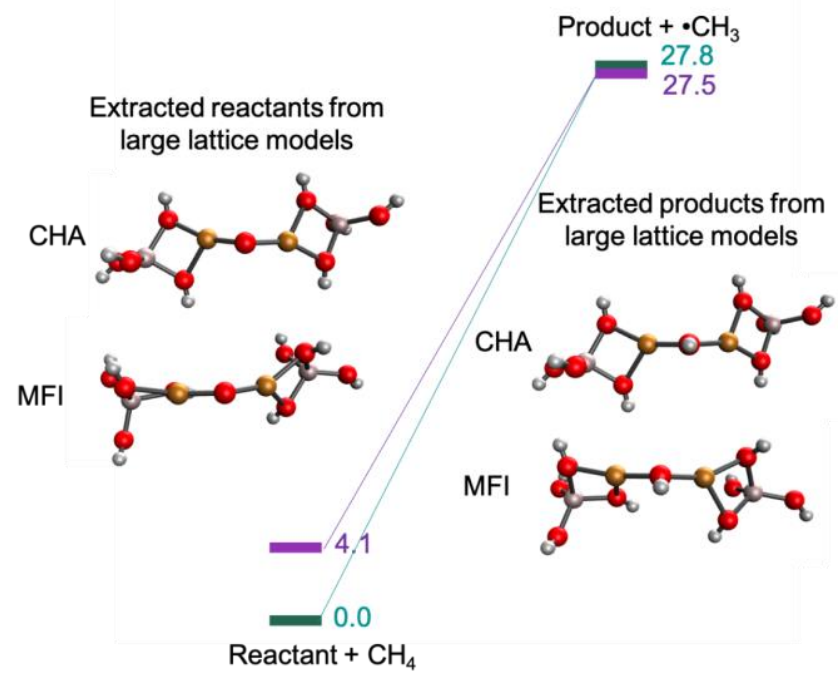

Figure 8. Relative stability of extracted $\mathrm{Cu}-\mathrm{O}-\mathrm{Cu}$ reactant and $\mathrm{Cu}-\mathrm{OH}-\mathrm{Cu}$ product cores for MFI (green) and $\mathrm{CHA}$ (purple).

MFI while the $\mathrm{Cu}-\mathrm{OH}-\mathrm{Cu}$ product was calculated to be only $0.3 \mathrm{kcal} / \mathrm{mol}$ higher in $\mathrm{Cu}$ $\mathrm{CHA}$ than in $\mathrm{Cu}-\mathrm{MFI}$. This indicates that the higher $\mathrm{OH}$ bond strength in $\mathrm{CHA}$ derives from a destabilization of the reactant $\mathrm{Cu}-\mathrm{O}-\mathrm{Cu}$ core imposed by the $\mathrm{CHA}$ lattice.

As mentioned earlier in the study, the main structural differences between the reactant cores of $\mathrm{CHA}$ and $\mathrm{MFI}$ are the angle of the $\mathrm{Cu}-\mathrm{O}-\mathrm{Cu}$ core $\left(120^{\circ}\right.$ in $\mathrm{MFI}$ and $140^{\circ}$ in $\mathrm{CHA}$ ) and the rotation of the bidentate oxygen ligands with respect to the $\mathrm{Cu}-\mathrm{O}$ Cu plane (close to $90^{\circ} / 0^{\circ}$ in $\mathrm{MFI}$ and $90^{\circ} / 90^{\circ}$ in $\mathrm{CHA}$ ). The contributions of these differences to the relative destabilization of $4.1 \mathrm{kcal} / \mathrm{mol}$ of the reactant core in $\mathrm{CHA}$ were evaluated using a series of small models (Experimental Section 10 in SI). A series of fixed ligand rotations was evaluated $\left(0^{\circ} / 0^{\circ}, 90^{\circ} / 0^{\circ},+45^{\circ} / 45^{\circ}\right.$ and $\left.90^{\circ} / 90^{\circ}\right)$ with respect to the $\mathrm{Cu}-\mathrm{O}-\mathrm{Cu}$ plane. These ligand rotation sets were analyzed for three $\mathrm{Cu}-\mathrm{O}-$ $\mathrm{Cu}$ angles $\left(161^{\circ}\right.$ from unconstrained optimization, $140^{\circ}$ to reflect $\mathrm{MFI}$ and $120^{\circ}$ to reflect 
$\mathrm{CHA}$ ). The relative energies for these models are given in Table 5 and their structure and LUMOs in Figure S14. Table 5 shows that for models with the same bidentate oxygen ligand rotations, the Cu-O-Cu angle does not significantly affect the energy. The models with the two bidentate oxygen pairs in the same plane as each other (rotated $0^{\circ} / 0^{\circ}$ and $90^{\circ} / 90^{\circ}$ with respect to the Table 5: Comparison of energies $(\mathrm{kcal} / \mathrm{mol})$ of models with various $\mathrm{Cu}-\mathrm{O}-\mathrm{Cu}$ angles and bidentate oxygen ligand rotation.

\begin{tabular}{c|ccc} 
Energy (kcal/mol) & \multicolumn{3}{|c}{ Cu-O-Cu angle } \\
\hline $\begin{array}{c}\text { Bidentate Oxygen Ligand Rotations } \\
\text { (with respect to the Cu-O-Cu plane) }\end{array}$ & $161^{\circ}$ & $140^{\circ}$ & $120^{\circ}$ \\
\hline$+45^{\circ} / 4^{\circ}$ & 0.4 & 1.4 & 0.2 \\
$0^{\circ} / 0^{\circ}$ & 6.4 & 7.2 & $14.5^{*}$ \\
$90^{\circ} / 0^{\circ}$ & 0.0 & 2.5 & 0.3 \\
$90^{\circ} / 90^{\circ}$ & 6.7 & 5.5 & 5.9 \\
\hline
\end{tabular}

$\left({ }^{*}\right)$ larger energy difference due to steric interaction between two in plane $\mathrm{Al} \mathrm{T}$ ligands at the acute $120^{\circ}$ angle.

Cu-O-Cu plane) are calculated to be $\sim 6 \mathrm{kcal} / \mathrm{mol}$ higher in energy than those with ligand sets rotated by $90^{\circ}$ from each other (rotated $+45^{\circ} / 45^{\circ}$ and $90^{\circ} / 0^{\circ}$ with respect to the $\mathrm{Cu}-\mathrm{O}-\mathrm{Cu}$ plane) across all evaluated $\mathrm{Cu}-\mathrm{O}-\mathrm{Cu}$ angles. The actual rotation of the bidentate ligands with respect to the $\mathrm{Cu}-\mathrm{O}-\mathrm{Cu}$ plane does not significantly impact the energy, only their rotations with respect to each other.

The bidentate O-AI-O T-site ligation on each $\mathrm{Cu}$ results in a highest energy singly occupied $d x^{2}-y^{2}$ orbital on each metal. The $\left[\mathrm{Cu}_{2} \mathrm{O}\right]^{2+}$ models with the bidentate oxygen ligands in the same plane as each other (Figure 9, right) have two frontier molecular orbitals (FMOs) (the $\beta$ LUMO and $\beta$ LUMO +1$)$ that are the $(-)$ and $(+)$ combinations, respectively, of the $d x^{2}-y^{2}$ orbitals on each $\mathrm{Cu}(\mathrm{II})$, delocalized over the model. The $(+)$ combination (Figure 9 top right) of the two $\mathrm{Cu} \mathrm{d} \mathrm{x}^{2}-\mathrm{y}^{2}$ orbitals interacts with an OOP oxo $2 p$ orbital leading to $29.8 \%$ oxo character while the (-) combination (Figure 9, bottom right) has only a limited interaction with the IP oxo $2 p$ orbital and thus a small amount $(8.3 \%)$ of oxo character. In the models with ligand sets rotated $90^{\circ}$ from each other, the 
two FMOs are again $(+)$ and $(-)$ combinations of $d x^{2}-y^{2}$ orbitals but now each is localized on a different $\mathrm{Cu}$ (II) which interacts with a different oxo $\mathrm{p}$ orbital, resulting in 24\% oxo character for both combinations (Figure 9, left).

$161^{\circ} \mathrm{Cu}-\mathrm{O}-\mathrm{Cu}$
$+45^{\circ} /-45^{\circ}$ dinedra

$\beta$ LUMO+1

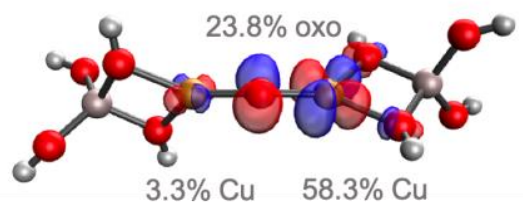

$\beta$ LUMO

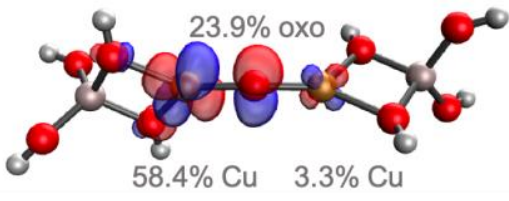

Figure 9. Comparison of FMOs for bidentate oxygen ligands rotated $90^{\circ}$ from each other (left) and in the same plane (right) (triplet ground state; see SI Figure S13 for the full series). $161^{\circ} \mathrm{Cu}-\mathrm{O}-\mathrm{Cu}$ $90^{\circ} / 90^{\circ}$ dihedral

$\beta$ LUMO+1

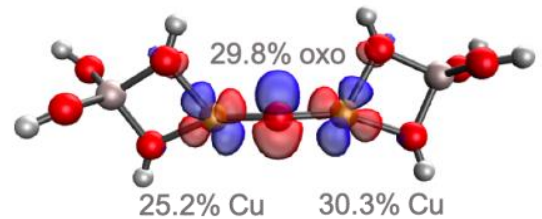

$\beta$ LUMO

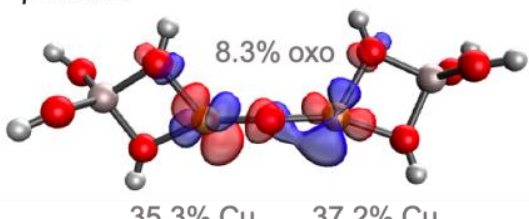

$35.3 \% \mathrm{Cu} \quad 37.2 \% \mathrm{Cu}$

character distributed over the two LUMOs relative to the $0^{\circ}$ ligand rotation on Figure 9, right $(47.7 \%$ vs $38.1 \%$ total oxo character). This results in the stabilization of this active

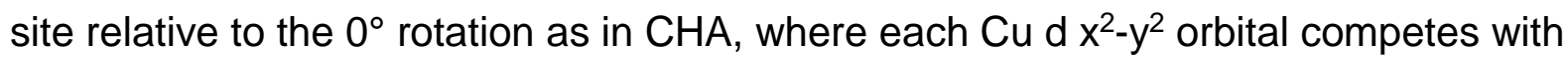
the same oxo $2 p$ orbital for bonding. Thus, the copper atoms in CHA bind less strongly to the oxo than in MFI destabilizing the $\left[\mathrm{Cu}_{2} \mathrm{O}\right]^{2+}$ active site and priming it for reactivity. This conclusion holds throughout the series of small models with varying $\mathrm{Cu}-\mathrm{O}-\mathrm{Cu}$ angles in Figure S14.

\section{Discussion}

$\mathrm{A}\left[\mathrm{Cu}_{2} \mathrm{O}\right]^{2+}$ core with an angle of $120^{\circ}$ is identified as the active site in $\mathrm{Cu}-\mathrm{CHA}$ that converts methane to methanol at low temperature. This $\left[\mathrm{Cu}_{2} \mathrm{O}\right]^{2+}$ active site assignment in $\mathrm{Cu}-\mathrm{CHA}$ is different from previous proposals of multiple $\mathrm{Cu} / \mathrm{O}$ species 
contributing to the features observed in the $\mathrm{Cu}-\mathrm{CHA}$ rR spectrum. ${ }^{15,16}$ These previous assignments were largely based on empirical correlations to $\mathrm{Cu} / \mathrm{O}$ structures present in model and enzyme literature. ${ }^{10,35,42,43}$ However, in the present study additional new data were collected including the rR spectrum of $\mathrm{Cu}-\mathrm{CHA}$ activated with $\mathrm{N}_{2} \mathrm{O}$, the ${ }^{18} \mathrm{O}_{2}$ perturbation on the rR spectrum, the full resonance enhancement profile over the associated absorption feature and an extension of the $\mathrm{rR}$ spectrum to the higher energy overtone region. These additional experiments enabled an unambiguous assignment of the $\mathrm{rR}$ features of $\mathrm{Cu}-\mathrm{CHA}$, highlighting the importance of rigorous spectroscopy and the possibility of inaccurate assignments relying on empirical correlations to define an intermediate.

From rR, the $\left[\mathrm{Cu}_{2} \mathrm{O}\right]^{2+}$ site defined in $\mathrm{Cu}-\mathrm{CHA}$ has a more acute $\mathrm{Cu}-\mathrm{O}-\mathrm{Cu}$ angle than the one defined in Cu-MFI and from kinetic experiments is found to have a lower enthalpic barrier by $2.5 \mathrm{kcal} / \mathrm{mol}$. DFT modeling reproduces the experimental results and indicates that this difference in reactivity is due to the thermodynamic driving force associated with the stronger $\mathrm{O}-\mathrm{H}$ bond formed in the $\left[\mathrm{Cu}_{2} \mathrm{OH}\right]^{2+} \mathrm{CHA}$ intermediate generated in the HAA reaction. While the $\left[\mathrm{Cu}_{2} \mathrm{OH}\right]^{2+}$ intermediates in the two lattices are similar in energy, the reactant $\left[\mathrm{Cu}_{2} \mathrm{O}\right]^{2+}$ site in $\mathrm{Cu}-\mathrm{CHA}$ is destabilized compared to that in Cu-MFI and this lowers the activation barrier in $\mathrm{Cu}-\mathrm{CHA}$. This destabilization is not due to the change in the $\mathrm{Cu}-\mathrm{O}-\mathrm{Cu}$ angle but derives from the lattice-imposed relative orientations of the two bidentate oxygen ligand sets.

The results from the present study on $\mathrm{Cu}-\mathrm{CHA}$ and $\mathrm{Cu}-\mathrm{MFI}$ are different from what was found in our prior studies on $\mathrm{Cu}-\mathrm{MOR}$ where two $\left[\mathrm{Cu}_{2} \mathrm{O}\right]^{2+}$ sites are present with different reactivity but similar $\mathrm{Cu}-\mathrm{O}-\mathrm{Cu}$ structures. ${ }^{25}$ In $\mathrm{MOR}$, the two $\left[\mathrm{Cu}_{2} \mathrm{O}\right]^{2+}$ sites 
are located in different parts of the zeolite lattice, one in the constrained 8MR side pocket and one in a large 12MR channel. Their difference in the apparent activation is due to the large difference in physisorption enthalpy for the two sites $(\Delta \Delta \mathrm{H}=7.7 \mathrm{kcal} / \mathrm{mol})$ reflecting stabilization by the constrained pocket. In the present study, physisorption was calculated to be similar in both CHA and MFI (Figure 7, left side) and it is not a dominating contribution to the difference in apparent activation barriers between $\mathrm{CHA}$ and MFI. The lattice constraints associated with the bidentate T-site ligation in $\mathrm{CHA}$ impose a destabilizing geometry on the $[\mathrm{Cu}-\mathrm{O}-\mathrm{Cu}]^{2+}$ core, reminiscent of the entatic state in metalloproteins where protein constraints enforce an unstable geometry that is associated with high reactivity. ${ }^{1}$ It is interesting to note that the approximate perpendicular orientation of the bidentate O-Al-O T-Site ligand planes in MFI and their parallel orientation in CHA would reflect the lower and upper limits on this role of the zeolite lattice in activating a $\left[\mathrm{Cu}_{2} \mathrm{O}\right]^{2+}$ core. Improving upon the reactivity of $\left[\mathrm{Cu}_{2} \mathrm{O}\right]^{2+}$ in $\mathrm{Cu}-\mathrm{CHA}$ could occur via topologies with a more confined cage which still maintains coplanar geometry of the four lattice oxygen ligands. The latter not only depends on the zeolite topology, but also on the location of Al substitution which can, in some cases, be guided during the zeolite synthesis. ${ }^{44-46}$

Together, the previous study on MOR and the present study demonstrate two means through which a carefully chosen zeolite support can enhance the reactivity of a $\left[\mathrm{Cu}_{2} \mathrm{O}\right]^{2+}$ species, providing a direction for optimization towards room temperature reactivity. This would open up new applications for these materials, such as the ambient capturing of $\mathrm{CH}_{4}$ from dilute emission streams or from the atmosphere as a negative emission technology. ${ }^{19}$ 


\section{Notes:}

The authors declare no competing financial interest.

\section{Associated Content:}

The following information is available free of charge on the ACS Publications Website:

Experimental Section, PXRD patterns, nitrogen sorption isotherms, additional DR UVVis spectra and $r R$ spectra of $\mathrm{Cu}-\mathrm{CHA}, \mathrm{rR}$ of ${ }^{18} \mathrm{O}_{2}$ activated $\mathrm{Cu}-\mathrm{CHA}$, normal coordinate analysis of a Cu-O-Cu angle, Arrhenius plot of the reaction of $\mathrm{CH}_{4}$ with $\mathrm{Cu}-\mathrm{CHA}$ and $\mathrm{Cu}-$ MFI, DFT of small ring Cu-CHA and Cu-MFI models, DFT cluster model coordinates

\section{Author information:}

Corresponding Authors

*edward.solomon@stanford.edu

*robert.schoonheydt@telenet.be

*bert.sels@kuleuven.be

\section{Acknowledgments}

Funding for this work was provided by National Science Foundation Grant CHE1660611(to E.I.S.), the Stanford Woods Institute for the Environment, and the National Institutes of Health Grant R01DK031450 (to E.I.S.). Research Foundation - Flanders is acknowledged for grant G0A2216N (to B.F.S.), 11D4718N (to D.P.) and $1276021 \mathrm{~N}$ (to M.B.). 
For Table of Contents Only

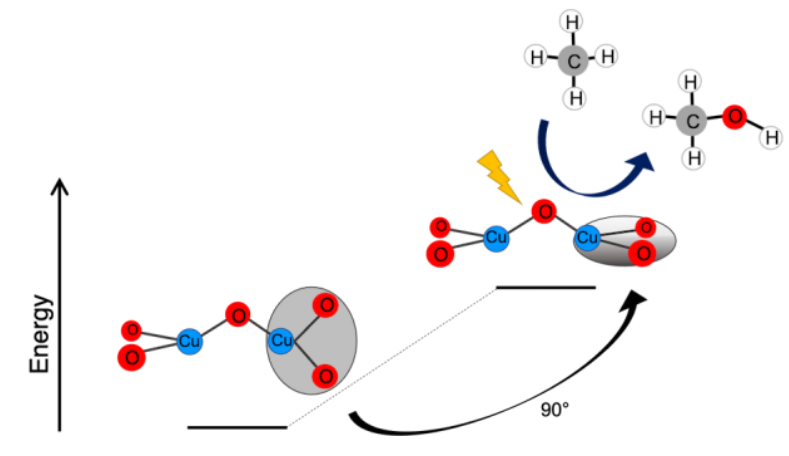




\section{References}

(1) Snyder, B. E. R.; Bols, M. L.; Schoonheydt, R. A.; Sels, B. F.; Solomon, E. I. Iron and Copper Active Sites in Zeolites and Their Correlation to Metalloenzymes. Chem. Rev. 2018, 118, 2718-2768.

(2) Hammond, C.; Conrad, S.; Hermans, I. Oxidative Methane Upgrading. ChemSusChem 2012, 5, 1668-1686.

(3) Banerjee, R.; Proshlyakov, Y.; Lipscomb, J. D.; Proshlyakov, D. A. Structure of the Key Species in the Enzymatic Oxidation of Methane to Methanol. Nature 2015, 518, 431-434.

(4) Castillo, R. G.; Banerjee, R.; Allpress, C. J.; Rohde, G. T.; Bill, E.; Que, L.; Lipscomb, J. D.; DeBeer, S. High-Energy-Resolution Fluorescence-Detected X-Ray Absorption of the Q Intermediate of Soluble Methane Monooxygenase. J. Am. Chem. Soc. 2017, 139, $18024-18033$.

(5) Cutsail, G. E.; Banerjee, R.; Zhou, A.; Que, L.; Lipscomb, J. D.; DeBeer, S. HighResolution Extended X-Ray Absorption Fine Structure Analysis Provides Evidence for a Longer Fe...Fe Distance in the $\mathrm{Q}$ Intermediate of Methane Monooxygenase. J. Am.

Chem. Soc. 2018, 140, 16807-16820.

(6) Culpepper, M. A.; Rosenzweig, A. C. Architecture and Active Site of Particulate Methane Monooxygenase. Crit. Rev. Biochem. Mol. Biol. 2012, 47, 483-492.

(7) Ross, M. O.; MacMillan, F.; Wang, J.; Nisthal, A.; Lawton, T. J.; Olafson, B. D.; Mayo, S. L.; Rosenzweig, A. C.; Hoffman, B. M. Particulate Methane Monooxygenase Contains Only Mononuclear Copper Centers. Science 2019, 364, 566-570.

(8) Vanelderen, P.; Snyder, B. E. R.; Tsai, M.-L.; Hadt, R. G.; Vancauwenbergh, J.; Coussens, O.; Schoonheydt, R. A.; Sels, B. F.; Solomon, E. I. Spectroscopic Definition of the Copper Active Sites in Mordenite: Selective Methane Oxidation. J. Am. Chem. Soc. 2015, 137, 6383-6392. 
(9) Snyder, B. E. R.; Vanelderen, P.; Bols, M. L.; Hallaert, S. D.; Böttger, L. H.; Ungur, L.;

Pierloot, K.; Schoonheydt, R. A.; Sels, B. F.; Solomon, E. I. The Active Site of Low-

Temperature Methane Hydroxylation in Iron-Containing Zeolites. Nature 2016, 536, $317-$ 321.

(10) Woertink, J. S.; Smeets, P. J.; Groothaert, M. H.; Vance, M. A.; Sels, B. F.; Schoonheydt, R. A.; Solomon, E. I. A [Cu 2 O] 2+ Core in Cu-ZSM-5, the Active Site in the Oxidation of Methane to Methanol. Proc. Natl. Acad. Sci. 2009, 106, 18908-18913.

(11) Dinh, K. T.; Sullivan, M. M.; Serna, P.; Meyer, R. J.; Dincă, M.; Román-Leshkov, Y. Viewpoint on the Partial Oxidation of Methane to Methanol Using Cu- and Fe-Exchanged Zeolites. ACS Catal. 2018, 8, 8306-8313.

(12) Newton, M. A.; Knorpp, A. J.; Sushkevich, V. L.; Palagin, D.; van Bokhoven, J. A. Active Sites and Mechanisms in the Direct Conversion of Methane to Methanol Using $\mathrm{Cu}$ in Zeolitic Hosts: A Critical Examination. Chem. Soc. Rev. 2020, 49, 1449-1486.

(13) Snyder, B. E. R.; Böttger, L. H.; Bols, M. L.; Yan, J. J.; Rhoda, H. M.; Jacobs, A. B.; Hu, M. Y.; Zhao, J.; Alp, E. E.; Hedman, B.; Hodgson, K. O.; Schoonheydt, R. A.; Sels, B. F.; Solomon, E. I. Structural Characterization of a Non-Heme Iron Active Site in Zeolites That Hydroxylates Methane. Proc. Natl. Acad. Sci. 2018, 115, 4565-4570.

(14) Tabor, E.; Dedecek, J.; Mlekodaj, K.; Sobalik, Z.; Andrikopoulos, P. C.; Sklenak, S. Dioxygen Dissociation over Man-Made System at Room Temperature to Form the Active a-Oxygen for Methane Oxidation. Sci. Adv. 2020, 6, 1-9.

(15) Ipek, B.; Wulfers, M. J.; Kim, H.; Göltl, F.; Hermans, I.; Smith, J. P.; Booksh, K. S.; Brown, C. M.; Lobo, R. F. Formation of [ $\mathrm{Cu} 2 \mathrm{O} 2$ ] 2+ and [ $\mathrm{Cu} 2 \mathrm{O}] 2+$ toward C-H Bond Activation in Cu-SSZ-13 and Cu-SSZ-39. ACS Catal. 2017, 7, 4291-4303.

(16) Pappas, D. K.; Borfecchia, E.; Dyballa, M.; Pankin, I. A.; Lomachenko, K. A.; Martini, A.; Signorile, M.; Teketel, S.; Arstad, B.; Berlier, G.; Lamberti, C.; Bordiga, S.; Olsbye, U.; Lillerud, K. P.; Svelle, S.; Beato, P. Methane to Methanol: Structure-Activity 
Relationships for Cu-CHA. J. Am. Chem. Soc. 2017, 139, 14961-14975.

(17) Grundner, S.; Markovits, M. A. C.; Li, G.; Tromp, M.; Pidko, E. A.; Hensen, E. J. M.; Jentys, A.; Sanchez-Sanchez, M.; Lercher, J. A. Single-Site Trinuclear Copper Oxygen Clusters in Mordenite for Selective Conversion of Methane to Methanol. Nat. Commun. 2015, 6, 7546.

(18) Tomkins, P.; Mansouri, A.; Bozbag, S. E.; Krumeich, F.; Park, M. B.; Alayon, E. M. C.; Ranocchiari, M.; van Bokhoven, J. A. Isothermal Cyclic Conversion of Methane into Methanol over Copper- Exchanged Zeolite at Low Temperature. Angew. Chemie Int. Ed. 2016, 55, 5467-5471.

(19) Jackson, R. B.; Solomon, E. I.; Canadell, J. G.; Cargnello, M.; Field, C. B. Methane Removal and Atmospheric Restoration. Nat. Sustain. 2019, 2, 436-438.

(20) Xin, Y.; Li, Q.; Zhang, Z. Zeolitic Materials for DeNO $x$ Selective Catalytic Reduction. ChemCatChem 2018, 10, 29-41.

(21) Zhang, R.; Liu, N.; Lei, Z.; Chen, B. Selective Transformation of Various NitrogenContaining Exhaust Gases toward N 2 over Zeolite Catalysts. Chem. Rev. 2016, 116, 3658-3721.

(22) Beale, A. M.; Gao, F.; Lezcano-Gonzalez, I.; Peden, C. H. F.; Szanyi, J. Recent Advances in Automotive Catalysis for NO $\times$ Emission Control by Small-Pore Microporous Materials. Chem. Soc. Rev. 2015, 44, 7371-7405.

(23) Borfecchia, E.; Beato, P.; Svelle, S.; Olsbye, U.; Lamberti, C.; Bordiga, S. Cu-CHA - a Model System for Applied Selective Redox Catalysis. Chem. Soc. Rev. 2018, 47, 80978133.

(24) Ipek, B.; Lobo, R. F. Catalytic Conversion of Methane to Methanol on Cu-SSZ-13 Using N $2 \mathrm{O}$ as Oxidant. Chem. Commun. 2016, 52, 13401-13404.

(25) Snyder, B. E. R.; Vanelderen, P.; Schoonheydt, R. A.; Sels, B. F.; Solomon, E. I. SecondSphere Effects on Methane Hydroxylation in Cu-Zeolites. J. Am. Chem. Soc. 2018, 140, 
9236-9243.

(26) Negri, C.; Signorile, M.; Porcaro, N. G.; Borfecchia, E.; Berlier, G.; Janssens, T. V. W.; Bordiga, S. Dynamic Cull/Cul Speciation in Cu-CHA Catalysts by in Situ Diffuse Reflectance UV-Vis-NIR Spectroscopy. Appl. Catal. A Gen. 2019, 578, 1-9.

(27) Oord, R.; Schmidt, J. E.; Weckhuysen, B. M. Methane-to-Methanol Conversion over Zeolite Cu-SSZ-13, and Its Comparison with the Selective Catalytic Reduction of NOx with NH3. Catal. Sci. Technol. 2018, 8, 1028-1038.

(28) Giordanino, F.; Vennestrøm, P. N. R.; Lundegaard, L. F.; Stappen, F. N.; Mossin, S.; Beato, P.; Bordiga, S.; Lamberti, C. Characterization of Cu-Exchanged SSZ-13: A Comparative FTIR, UV-Vis, and EPR Study with Cu-ZSM-5 and Cu- $\beta$ with Similar Si/AI and Cu/Al Ratios. Dalt. Trans. 2013, 42, 12741-12761.

(29) Godiksen, A.; Stappen, F. N.; Vennestrøm, P. N. R.; Giordanino, F.; Rasmussen, S. B.; Lundegaard, L. F.; Mossin, S. Coordination Environment of Copper Sites in Cu-CHA Zeolite Investigated by Electron Paramagnetic Resonance. J. Phys. Chem. C 2014, 118, 23126-23138.

(30) Li, H.; Paolucci, C.; Khurana, I.; Wilcox, L. N.; Göltl, F.; Albarracin-Caballero, J. D.; Shih, A. J.; Ribeiro, F. H.; Gounder, R.; Schneider, W. F. Consequences of Exchange-Site Heterogeneity and Dynamics on the UV-Visible Spectrum of Cu-Exchanged SSZ-13. Chem. Sci. 2019, 10, 2373-2384.

(31) Wulfers, M. J.; Teketel, S.; Ipek, B.; Lobo, R. F. Conversion of Methane to Methanol on Copper-Containing Small-Pore Zeolites and Zeotypes. Chem. Commun. 2015, 51, 44474450 .

(32) Beznis, N. V.; Weckhuysen, B. M.; Bitter, J. H. Cu-ZSM-5 Zeolites for the Formation of Methanol from Methane and Oxygen: Probing the Active Sites and Spectator Species. Catal. Letters 2010, 138, 14-22.

(33) Sushkevich, V. L.; Palagin, D.; Ranocchiari, M.; van Bokhoven, J. A. Selective Anaerobic 
Oxidation of Methane Enables Direct Synthesis of Methanol. Science 2017, 356, 523527.

(34) Brezicki, G.; Kammert, J. D.; Gunnoe, T. B.; Paolucci, C.; Davis, R. J. Insights into the Speciation of $\mathrm{Cu}$ in the $\mathrm{Cu}-\mathrm{H}-M o r d e n i t e ~ C a t a l y s t$ for the Oxidation of Methane to Methanol. ACS Catal. 2019, 9, 5308-5319.

(35) Baldwin, M. J.; Ross, P. K.; Pate, J. E.; Tyeklar, Z.; Karlin, K. D.; Solomon, E. I.; Tyeklàr, Z.; Karlin, K. D.; Solomon, E. I.; Pate, J. E.; Tyeklàr, Z.; Karlin, K. D. Spectroscopic and Theoretical Studies of an End-on Peroxide-Bridged Coupled Binuclear Copper(II) Model Complex of Relevance to the Active Sites in Hemocyanin and Tyrosinase. J. Am. Chem. Soc. 1991, 113, 8671-8679.

(36) Brunold, T. C.; Tamura, N.; Kitajima, N.; Moro-oka, Y.; Solomon, E. I. Spectroscopic Study of [Fe 2 (O 2 )(OBz) $2\left\{\mathrm{HB}\left(\mathrm{Pz}^{\prime}\right) 3\right\} 2$ ]: Nature of the $\mu-1,2$ Peroxide-Fe(III) Bond and Its Possible Relevance to O 2 Activation by Non-Heme Iron Enzymes. J. Am. Chem. Soc. $1998,120,5674-5690$.

(37) Li, L.; Solomon, E. I.; Lucas, H. R.; Karlin, K. D.; Sarjeant, A. A. N.; Vance, M. A. Toluene and Ethylbenzene Aliphatic C-H Bond Oxidations Initiated by a Dicopper(II)- $\mu-1,2-$ Peroxo Complex. J. Am. Chem. Soc. 2009, 131, 3230-3245.

(38) Lee, Y.; Park, G. Y.; Lucas, H. R.; Vajda, P. L.; Kamaraj, K.; Vance, M. A.; Milligan, A. E.; Woertink, J. S.; Slegler, M. A.; Narducci Sarjeant, A. A.; Zakharov, L. N.; Rheingold, A. L.; Solomon, E. I.; Karlin, K. D. Copper(I)/O2 Chemistry with Imidazole Containing Tripodal Tetradentate Ligands Leading to $\mu$-1,2-Peroxo-Dicopper(II) Species. Inorg. Chem. 2009, 48, 11297-11309.

(39) Maiti, D.; Fry, H. C.; Woertink, J. S.; Vance, M. A.; Solomon, E. I.; Karlin, K. D. A 1:1 Copper-Dioxygen Adduct Is an End-on Bound Superoxo Copper(II) Complex Which Undergoes Oxygenation Reactions with Phenols. J. Am. Chem. Soc. 2007, 129, 264265. 
(40) Wing, R. M.; Callahan, K. P. Characterization of Metal-Oxygen Bridge Systems. Inorg. Chem. 1969, 8, 871-874.

(41) Marcus, R. A. Theoretical Relations among Rate Constants, Barriers, and Bronsted Slopes of Chemical Reactions. J. Phys. Chem. 1968, 72, 891-899.

(42) Mirica, L. M.; Ottenwaelder, X.; Stack, T. D. P. Structure and Spectroscopy of Copper-Dioxygen Complexes. Chem. Rev. 2004, 104, 1013-1046.

(43) Baldwin, M. J.; Roo, D. E.; Pate, J. E.; Fujisawa, K.; Kitajima, N.; Solomon, E. I. Spectroscopic Studies of Side-On Peroxide-Bridged Binuclear Copper(II) Model Complexes of Relevance to Oxyhemocyanin and Oxytyrosinase. J. Am. Chem. Soc. 1992, 114, 10421-10431.

(44) Di lorio, J. R.; Gounder, R. Controlling the Isolation and Pairing of Aluminum in Chabazite Zeolites Using Mixtures of Organic and Inorganic Structure-Directing Agents. Chem. Mater. 2016, 28, 2236-2247.

(45) Devos, J.; Bols, M. L.; Plessers, D.; Goethem, C. Van; Seo, J. W.; Hwang, S. J.; Sels, B. F.; Dusselier, M. Synthesis-Structure-Activity Relations in Fe-CHA for C-H Activation: Control of Al Distribution by Interzeolite Conversion. Chem. Mater. 2020, 32, 273-285. (46) Di lorio, J. R.; Nimlos, C. T.; Gounder, R. Introducing Catalytic Diversity into Single-Site Chabazite Zeolites of Fixed Composition via Synthetic Control of Active Site Proximity. ACS Catal. 2017, 7, 6663-6674. 